\title{
The outer membrane of lipid A-deficient Escherichia coli mutant LH530 has reduced levels of OmpF and leaks periplasmic enzymes
}

\author{
Marjatta Nurminen, Laura Hirvas and Martti Vaara
}

Author for correspondence: Marjatta Nurminen. Fax: +3584346382.

Department of Bacteriology and Immunology, Haartman Institute, PO Box 21 (Haartmaninkatu 3), SF00014 University of Helsinki, Helsinki, Finland

\begin{abstract}
We have previously described a new Escherichia coli K-12 mutant, LH530, which has a defective outer membrane. LH530 is very sensitive to hydrophobic antibiotics, does not grow at $42{ }^{\circ} \mathrm{C}$ and synthesizes reduced amounts of lipid $A$. Phenotypically LH530 is very similar to the known lipid A biosynthesis mutants of E. coli and Salmonella typhimurium. Its genetic defect is not known, but the defect is suppressed by multiple copies of ORF195. Here we show that at $37{ }^{\circ} \mathrm{C}$ LH530 contains a reduced amount of the OmpF porin and that it leaks periplasmic $\beta$-lactamase at $37{ }^{\circ} \mathrm{C}$ and $42{ }^{\circ} \mathrm{C}$. We further show that ORF195, when present at low copy number, restores the antibiotic resistance and lipid $\mathrm{A}$ biosynthesis of LH530 at $28{ }^{\circ} \mathrm{C}$, but not at higher temperatures. In contrast, OmpF expression is restored at $37^{\circ} \mathrm{C}$.
\end{abstract}

Keywords: Escherichia coli, ORF195, OmpF, periplasmic enzymes, outer membrane permeability

\section{INTRODUCTION}

Lipopolysaccharide (LPS) is an essential component of the outer membranes (OMs) of Gram-negative bacteria, and mutations affecting the structure of LPS severely decrease the ability to grow in normal environments (Nikaido \& Vaara, 1987). Defects in the LPS inner core region render the OM permeable to hydrophobic antibiotics and sensitize the bacteria to these agents. However, mutations affecting the early phase of lipid A biosynthesis are lethal to the bacteria. Thus, leaky or conditional, e.g. thermosensitive, lipid A mutants are the best choice for studying the lipid A biosynthesis pathway. At permissive temperatures lipid A mutants are even more sensitive to hydrophobic antibiotics than the mutants that are defective in synthesis of the inner core part of the LPS (Vaara, 1993). Moreover, at nonpermissive temperatures lipid A deficiency leads to leakage of periplasmic enzymes (Vuorio \& Vaara, 1992).

The proper trimerization and export of porin proteins requires a specific LPS structure (Sen \& Nikaido, 1991) and deep rough mutants contain reduced amounts of OM proteins (Ames et al., 1974; for review, see Nikaido $\&$ Vaara, 1985). The relative abundance of OmpC and $\mathrm{OmpF}$ is a function of the temperature and osmolarity

Abbreviation: $O M$, outer membrane. of the growth medium (Pratt et al., 1996). envZ and ompR control porin gene transcription in response to osmolarity, and the antisense RNA, micF, influences $o m p F$ translation. OmpF deficiency can also result from dsbA mutations (Pugsley, 1993) and pleiotropic tolC mutations (Misra \& Reeves, 1987; Forst \& Inouye, 1988). DbsA is a periplasmic disulphide oxidoreductase responsible for the formation of disulphide bonds in periplasmic proteins and in periplasmic domains of inner and outer membrane proteins as well as secreted proteins (Bardwell, 1994). TolC probably affects OmpF levels by increasing micF expression.

Recently, we isolated a new E. coli K-12 mutant, LH530 (Hirvas et al., 1997), which in many aspects resembles the known lipid A biosynthesis mutants. It is hypersusceptible to hydrophobic antibiotics, grows in a heatsensitive manner and has a decreased rate of lipid A biosynthesis. The defect is suppressed by multiple, but not by low copy numbers, of ORF195 (Hirvas et al., 1997), an ORF located in the $76 \mathrm{~min}$ region of the chromosome (Sofia et al., 1994).

In this work we show that LH530 leaks periplasmic $\beta$ lactamase and is deficient in $\mathrm{OmpF}$ protein at higher temperatures. Further we compare the effect of low- and high-copy expression of ORF195 in the mutant on the rate of lipid A biosynthesis and on the expression of OmpF. 


\section{METHODS}

Bacterial strains and plasmids and general DNA manipulations. The OM mutant LH530 originates from JM105 (Yanisch-Perron et al., 1985) and has been described previously (Hirvas et al., 1997). DME553 is an ompF deletion mutant of E. coli K-12 (Misra \& Benson, 1988). The pUC19derived plasmids, pLH29 (containing ORF376 and ORF195) and pLH31 (containing ORF195), as well as the low-copynumber vector pACYC184-derived plasmid pLH37 (containing ORF376 and ORF195) have been described previously (Hirvas et al., 1997). General DNA manipulations were carried out as described by Sambrook et al., (1989).

Measurement of leakage of periplasmic enzymes and lipid A biosynthesis rate. The leakage of $\beta$-lactamase and glucose-6phosphate dehydrogenase from bacteria was measured essentially as described by Vuorio \& Vaara (1992) using the methods of O'Callaghan et al. (1972) and Langdon (1966), respectively.

The ratio of LPS to phospholipid biosynthesis in LH530 and its derivatives was assayed (Vuorio \& Vaara, 1995; Hirvas et al., 1997) after labelling their fatty acids with radiolabelled acetate in vivo at $28^{\circ} \mathrm{C}, 37^{\circ} \mathrm{C}$ and $42^{\circ} \mathrm{C}$.

Analysis of major OM proteins. LH530, JM105 and DME 553 $\left(o m p F^{-}\right)$were grown on L-plates at $28^{\circ} \mathrm{C}$ and $37^{\circ} \mathrm{C}$. Plasmidcontaining derivatives of LH530 were grown on L-plates containing $100 \mu \mathrm{g}$ ampicillin $\mathrm{ml}^{-1}$ or $30 \mu \mathrm{g}$ chloramphenicol $\mathrm{ml}^{-1}$. Approximately $10^{10}$ bacteria were suspended in $10 \mathrm{ml}$
$0.9 \% \mathrm{NaCl}$ and collected by centrifugation. Bacterial cell envelopes were isolated (Hirvas et al., 1991a) and their protein profiles analysed in 10\% SDS-PAGE (Laemmli, 1970). Gels were stained with Coomassie Blue, scanned by an Agfa Arcus II scanner and edited by Canvas 3.5 using a Macintosh $7500 / 100$ computer.

\section{RESULTS}

\section{Release of periplasmic enzymes}

We have previously shown that the OM of LH530 is permeable to hydrophobic agents (Hirvas et al., 1997). Here we studied whether its OM leaks periplasmic proteins, as does the OM of certain lipid A mutants. We therefore introduced pUC19 (encoding periplasmic $\beta$ lactamase) into LH530. As a control we introduced plasmid pLH31 into LH530. pLH31 is a pUC19 derivative and contains wild-type ORF195. A temperature shift from $28{ }^{\circ} \mathrm{C}$ to $37^{\circ} \mathrm{C}$ or $42^{\circ} \mathrm{C}$ induced approximately $39 \%$ and $45 \%$ leakage of the periplasmic $\beta$ lactamase from LH530(pUC19), respectively. With pLH31 the leakage was only $3.5 \%$ and $1.0 \%$, respectively (Fig. 1a, b). At $28{ }^{\circ} \mathrm{C}$ the leakage was less than $12 \%$ (data not shown). The cytoplasmic marker enzyme, glucose-6-phosphate dehydrogenase was not released (Fig. 1c, d).

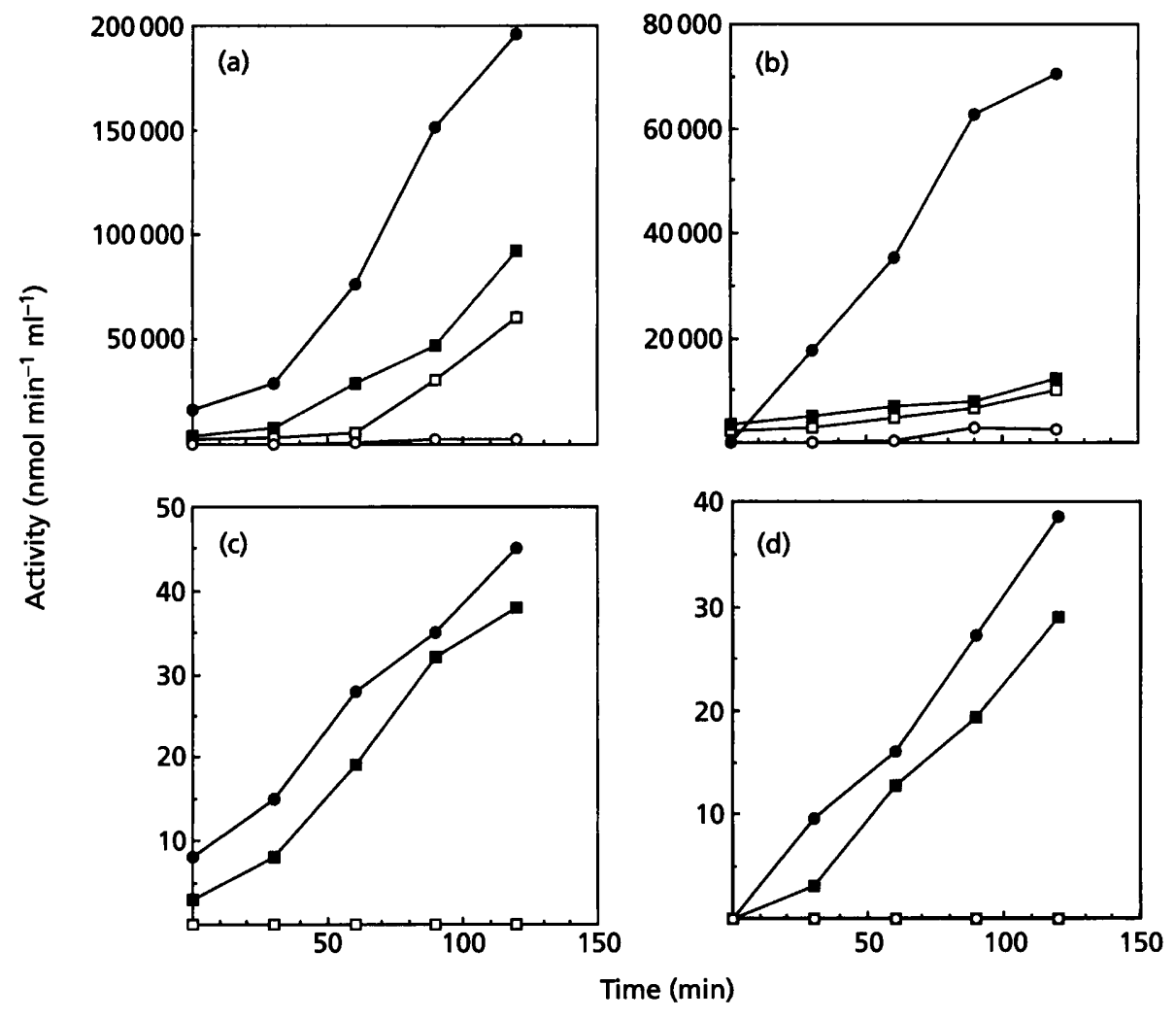

Fig. 1. Release of periplasmic $\beta$-lactamase and cytoplasmic glucose-6-phosphate dehydrogenase from derivatives of LH530. LH530 carrying either pUC19 $(\square, \square)$ or ORF195 $(O, O)$ was shifted from $28^{\circ} \mathrm{C}$ to $37^{\circ} \mathrm{C}(\mathrm{a}, \mathrm{c})$ or to $42^{\circ} \mathrm{C}(\mathrm{b}, \mathrm{d})$ at time zero. $\beta$-Lactamase $(a, b)$ and glucose-6-phosphate dehydrogenase $(c, d)$ activities in the growth medium $(0, \square)$ and the corresponding cellular activities $(\boldsymbol{O}, \boldsymbol{\square})$ are shown. 
Lipid A deficiency and leakage of periplasmic enzymes

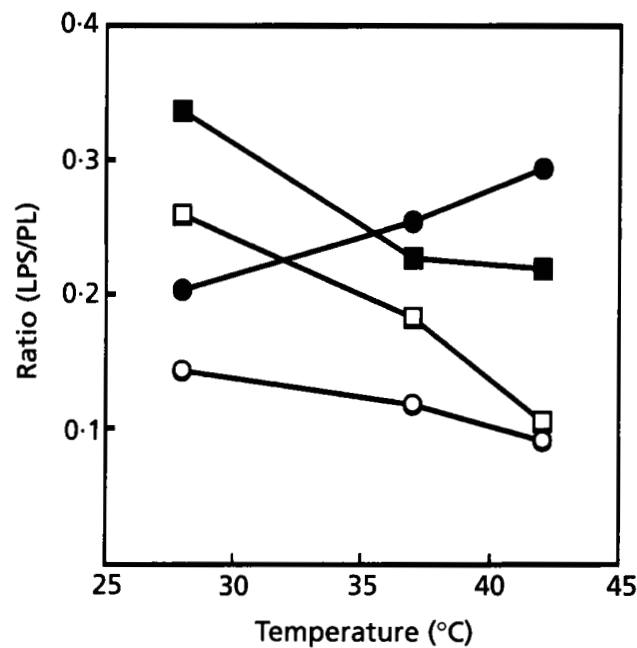

Fig. 2. The ratio of LPS to phospholipid biosynthesis (PL) at $28^{\circ} \mathrm{C}, 37^{\circ} \mathrm{C}$ and $42^{\circ} \mathrm{C}$ in LH530 (O), its parent JM105 (O), and its transformants carrying the multi-copy-number plasmid pLH29 ( $\square$ ) or the low-copy-number plasmid pLH37 ( $\square$ ).

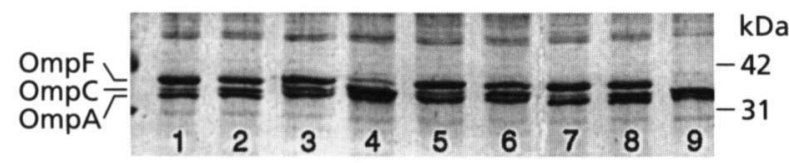

Fig. 3. SDS-PAGE of cell envelopes of JM105 and LH530 and its derivatives. Lanes: 1, 2, JM105; 3, 4, LH530; 5, 6, LH530 with multi-copy-number plasmid pLH29; 7, 8, LH530 with low-copynumber plasmid pLH37, each grown at $28^{\circ} \mathrm{C}$ and $37^{\circ} \mathrm{C}$, respectively; 9, DME553.

\section{The ratio of lipid $A$ to phospholipid biosynthesis of LH530 harbouring ORF195 in low- or multi-copy- number plasmids}

The low-copy-number plasmid, pLH37, was able to restore the ratio of lipid A to phospholipid biosynthesis in LH530 (Fig. 2) at $28^{\circ} \mathrm{C}$, but not at $37^{\circ} \mathrm{C}$ and $42^{\circ} \mathrm{C}$, where the ratio was about $50 \%$ and $42 \%$ of that of JM105, respectively. In our previous publication we showed that pLH37 also restores the antibiotic resistance of LH530 at $28^{\circ} \mathrm{C}$, but not at $37^{\circ} \mathrm{C}$ and $42{ }^{\circ} \mathrm{C}$. In contrast the multi-copy-number plasmid, pLH29, restores the ratio at all temperatures (Hirvas et al., 1997). Thus LPS levels correlate with the antibiotic susceptibility of LH530 and its derivatives.

\section{The protein composition of LH530}

Fig. 3 shows the OM protein profile of LH530 and its derivatives. At $37^{\circ} \mathrm{C}$ the profile of LH530 (lane 4) differed markedly from that of JM105 (lane 2) and resembled the profile of the OmpF-deficient strain DME553 (lane 9). The OmpC content was compensatorily increased. Both the multi-copy-number plasmid (pLH29) and low-copy-number plasmid (pLH37) restored the protein profile to one similar to JM105. At $28^{\circ} \mathrm{C}$ the OM protein profiles of JM105 (lane 1), LH530 (lane 3), and pLH29- (lane 5) and pLH37(lane 7) containing derivatives of LH530, were identical.

We have previously shown that high-copy expression of ORF195 (i.e. as in pLH29) is needed to suppress the defect of LH530 at all temperatures. Low-copy expression (pLH37) suppresses the defect totally at $28^{\circ} \mathrm{C}$, and almost totally at $37^{\circ} \mathrm{C}$, but does not restore the ability of LH530 to grow at $42^{\circ} \mathrm{C}$. Fig. 3 shows that both $\mathrm{pLH} 29$ and pLH37 were able to restore the OmpF content of LH530 at $37^{\circ} \mathrm{C}$ (lanes 6 and 8, respectively).

\section{DISCUSSION}

In this work we have further characterized the thermosensitive and lipid A-deficient mutant, LH530, and showed that at $37^{\circ} \mathrm{C}$ its $\mathrm{OM}$ is deficient in OmpF porin and leaks periplasmic $\beta$-lactamase. We also demonstrated that at $37^{\circ} \mathrm{C}$ the low-copy expression of ORF195 (the high-copy suppressor gene of LH530) only partially restores the rate of lipid A biosynthesis of LH530 to normal levels. However, it does restore its OmpF level.

In many respects LH530 resembles the well-characterized lipid A mutants $l p x A$ and $l p x D$ (Galloway \& Raetz, 1990; Hirvas et al., 1991b; Vaara, 1993; Helander et al., 1992, 1993; Vuorio \& Vaara, 1992) in being sensitive to hydrophobic antibiotics, in producing decreased amounts of LPS $\left(75 \%\right.$ at $28^{\circ} \mathrm{C}, 35-40 \%$ at $37^{\circ} \mathrm{C}$ and $42^{\circ} \mathrm{C}$; Hirvas et al., 1997) and in leaking periplasmic proteins. In addition we have demonstrated that the $l_{p x D}$ mutant is $\mathrm{OmpF}$ deficient at $37^{\circ} \mathrm{C}$ (unpublished observation) similar to LH530. However, LH530 does not harbour any mutation in $l p x A$ or $l p x D$ (Hirvas et al., 1997).

Our results indicate that the synthesis, assembly, or translocation of OmpF is dependent on certain level of LPS synthesis. Although some studies show that OmpA assembly differs from that of $\mathrm{OmpF}$ and $\mathrm{OmpC}$ (Ried et al., 1990; Bocquet-Pagès et al., 1981), it is difficult to explain why only OmpF is affected in LH530. A similar situation exists in certain deep rough mutants (for review, see Nikaido \& Vaara, 1985). However, another explanation for the OmpF deficiency could be that, among other periplasmic components, LH530 also leaks membrane-derived oligosaccharides as well as disulphide oxidoreductase encoded by $d s b A$. Mutations in $d s b A$ have been shown to decrease $\mathrm{OmpF}$ production in E. coli (Pugsley, 1993), and membrane-derived oligosaccharides have been proposed to have a role in recognition of the growth medium osmolarity (Pratt $e t$ al., 1996).

The OmpF deficiency is unlikely to be responsible for the antibiotic hypersensitivity of LH530, as it is sensitive even at $28^{\circ} \mathrm{C}$, where its OmpF level is normal. Furthermore, E. coli and S. typhimurium mutants lacking one or more of the porins or the OmpA protein, have an 
almost unaltered sensitivity to hydrophobic antibiotics (Chai \& Foulds, 1977; Lounatmaa \& Nurminen, 1977; van Alphen et al., 1977). The sensitivity of LH530 to hydrophobic antibiotics could be similar to that of deep rough LPS mutants, in which the relative lack of LPS in OM results in the compensatory appearance of glycerophospholipids in the outer leaflet of OM (for review, see Nikaido \& Vaara, 1985). As LH530 is also sensitive to large hydrophilic antibiotics, transient rupturing (and resealing) of the OM may be involved, as is also suggested for some lipid A biosynthesis mutants (Vaara, 1993).

Obviously, LH530 has a mutation in a gene essential in OM biosynthesis. Phenotypically the mutant resembles the known lipid A biosynthesis mutants of $E$. coli and $S$. typhimurium (Galloway \& Raetz, 1990; Hirvas et al., 1991b; Helander et al., 1992, 1993; Vuorio \& Vaara, 1992; Normark et al., 1969; Karow \& Georgopoulos, 1991, 1992; Karow et al., 1991). In contrast to mutants deficient in late acyl transferases (Lee et al., 1995; Clementz et al., 1995), there is no detectable change in the fatty acid composition of lipid A of mutant LH530 (Hirvas et al., 1997).

The mutation in LH530 does not necessarily involve any of the so far uncharacterized structural genes of lipid A biosynthesis. Thus, the characterization of mutant LH530 and the role of its suppressor gene, ORF195, in membrane assembly might give new insights into the regulation of the biosynthesis pathway for lipid A or into the translocation and biogenesis of OM components.

\section{ACKNOWLEDGEMENTS}

We thank Birgit Kuusela for excellent technical assistance and Helena Mäkelä, Pertti Koski, Suvi Taira and Timo Vaara for helpful discussions. This study was supported by Grant 8404 from the Academy of Finland and by Sigrid Juselius Foundation.

\section{REFERENCES}

van Alphen, L., Lugtenberg, B., von Boxtel, R. \& Vehoef, K. (1977). Architecture of the outer membrane of Escherichia coli K12. I. Action of phospholipase A2 and C and wild type strains and outer membrane mutants. Biochim Biophys Acta 466, 257-268.

Ames, G. F., Spudich, E. N. \& Nikaido, H. (1974). Protein composition of the outer membrane of Salmonella typhimurium, effect of lipopolysaccharide mutations. J Bacteriol 117, 406-416.

Bardwell, J. C. H. (1994). Building bridges, disulphide bond formation in the cell. Mol Microbiol 14, 199-205.

Bocquet-Pagès, C., Lazdunski, C. \& Lazdunski, A. (1981). Lipidsynthesis-dependent biosynthesis (or assembly) of major outer membrane proteins of Escherichia coli. Eur J Biochem 118, 105-111.

Chai, T.-J. \& Foulds, J. (1977). Escherichia coli K-12 tolF mutants, alterations in protein composition of the outer membrane. $J$ Bacteriol 130, 781-786.

Clementz, T., Bednarski, J. \& Raetz, C. R. H. (1995). Escherichia coli genes encoding KDO dependent acyltransferases that in- corporate laurate and myristate into Lipid A. In Abstracts of the Annual Meeting of the American Society for Biochemistry and Molecular Biology 9, p. 1311. Washington, DC: Federation of American Societies for Experimental Biology.

Forst, S. \& Inouye, M. (1988). Environmentally regulated gene expression for membrane proteins in Escherichia coli. Annu Rev Cell Biol 4, 21-42.

Galloway, S. \& Raetz, C. R. H. (1990). A mutant of Escherichia coli defective in the first step of endotoxin biosynthesis. J Biol Chem 265, 6394-6402.

Helander, I. M., Hirvas, L., Tuominen, J. \& Vaara, M. (1992). Preferential synthesis of heptaacyl lipopolysaccharide by the ssc permeability mutant of Salmonella typhimurium. Eur J Biochem 204, 1101-1106.

Helander, I. M., Lindner, B., Seydel, U. \& Vaara, M. (1993). Defective biosynthesis of the lipid A component of temperature sensitive firA (omsA) mutant of Escherichia coli. Eur J Biochem 212, 363-369.

Hirvas, L., Koski, P. \& Vaara, M. (1991a). The ompH gene of Yersinia enterocolitica, cloning, sequencing, expression, and comparison with known enterobacterial ompH sequences. $J$ Bacteriol 173, 1223-1229.

Hirvas, L., Koski, P. \& Vaara, M. (1991b). Identification and sequence analysis of the gene mutated in the conditionally lethal outer membrane permeability mutant SS-C of Salmonella typhimurium. EMBO J 10, 1017-1023.

Hirvas, L., Nurminen, M., Helander, I. M., Vuorio, R. \& Vaara, M. (1997). The lipid A biosynthesis deficiency of the Escherichia coli antibiotic-supersensitive mutant LH530 is suppressed by a novel locus, ORF195. Microbiology 143, 73-81.

Karow, M. \& Georgopoulos, C. (1991). Sequencing, mutational analysis, and transcriptional regulation of the Escherichia coli htrB gene. Mol Microbiol 5, 2285-2292.

Karow, M. \& Georgopoulos, C. (1992). Isolation and characterization of the Escherichia coli $m s b B$ gene, a multicopy suppressor of null mutations in the high-temperature requirement gene btrB. $J$ Bacteriol 174, 702-710.

Karow, M., Fayet, O., Cegielska, A., Ziegelhoffer, T. \& Georgopoulos, C. (1991). Isolation and characterization of the Escherichia coli htrB gene, whose product is essential for bacterial viability above $33^{\circ} \mathrm{C}$ in rich media. J Bacteriol 173, 741-750.

Laemmli, U. K. (1970). Cleavage of structural proteins during the assembly of the head of bacteriophage T4. Nature 227, 680-685.

Langdon, R. G. (1966). Glucose-6-phosphate dehydrogenase from erythrocytes. Methods Enzymol 9, 126-131.

Lee, N.-G., Sunshine, M. G., Engstrom, J. J., Gibson, B. W. \& Apicella, M. A. (1995). Mutation of the htrB locus of Haemophilus influenzae nontypable strain 2019 is associated with modifications of lipid A and phosphorylation of the lipo-oligosaccharide. J Biol Chem 270, 27151-27159.

Lounatmaa, K. \& Nurminen, M. (1977). Electron microscopy of bacteriophage resistant mutants of Salmonella typhimurium deficient in major outer membrane proteins. FEMS Microbiol Lett 2, 317-322.

Misra, R. \& Benson, S. A. (1988). Isolation and characterization of OmpC porin mutants with altered porin properties. $J$ Bacteriol 170, 528-533.

Misra, R. \& Reeves, P. R. (1987). Role of $m i c F$ in the tolC-mediated regulation of OmpF, a major outer membrane protein of Escherichia coli K-12. J Bacteriol 169, 4722-4730.

Nikaido, H. \& Vaara, M. (1985). Molecular basis of bacterial outer membrane permeability. Microbiol Rev 49, 1-32. 
Nikaido, H. \& Vaara, M. (1987). Outer Membrane. In Escherichia coli and Salmonella typhimurium, Cellular and Molecular Biology, pp. 7-22. Edited by F. C. Neidhardt. Washington DC: American Society for Microbiology.

Normark, S., Boman, H. G. \& Mattson, E. (1969). Mutant of Escherichia coli with anomalous cell division and ability to decrease episomally and chromosomally mediated resistance to ampicillin and several other antibiotics. J Bacteriol 92, 1334-1342.

O'Callaghan, C. H., Morris, A., Kirby, S. M. \& Shigler, A. H. (1972). Novel method for detection of $\beta$-lactamase by using a chromogenic cephalosporin substrate. Antimicrob Agents Chemother 1, 283-288.

Pratt, L. A., Hsing, W., Gibson, K. E. \& Silhavy, T. J. (1996). From acids to osmZ: multiple factors influence synthesis of the $\mathrm{OmpF}$ and OmpC porins in Escherichia coli. Mol Microbiol 20, 911-917.

Pugsley, A. P. (1993). A mutation in the $d s b A$ gene coding for periplasmic disulfide oxidoreductase reduces transcription of the Escherichia coli ompF gene. Mol Gen Genet 237, 407-411.

Ried, G., Hindennach, I. \& Henning, U. (1990). Role of lipopolysaccharide in assembly of Escherichia coli outer membrane proteins OmpA, OmpC, and OmpF. J Bacteriol 172, 6048-6053.

Sambrook, J., Fritsch, E. F. \& Maniatis, T. (1989). Molecular Cloning: a Laboratory Manual, 2nd edn. Cold Spring Harbor, NY: Cold Spring Harbor Laboratory.
Sen, K. \& Nikaido, H. (1991). Trimerization of an in vitro synthesized OmpF porin of Escherichia coli outer membrane. $J$ Biol Chem 288, 11295-11300.

Sofia, H. J., Burland, V., Daniels, D. L., Plunkett, G., III \& Blattner, F. R. (1994). Analysis of the Escherichia coli genome. V. DNA sequence of the region from 76.0-81.5. Nucleic Acids Res 22, 2576-2586.

Vaara, M. (1993). Antibiotic-supersusceptible mutants of Escherichia coli and Salmonella typhimurium. Antimicrob Agents Chemother 37, 2255-2260.

Vuorio, R. \& Vaara, M. (1992). Mutants carrying conditionally lethal mutations in outer membrane genes oms $A$ and fir $A$ (ssc) are phenotypically similar, and $o m s A$ is allelic to firA. J Bacteriol 174, 7090-7097.

Vuorio, R. \& Vaara, M. (1995). Comparison of the phenotypes of lpxA and lpxD mutants of Escherichia coli. FEMS Microbiol Lett 134, 227-232.

Yanisch-Perron, C., Vieira, J. \& Messing, J. (1985). Improved M13 phage cloning vectors and host strains, nucleotide sequences of the M13mp18 and pUC19 vectors. Gene 33, 103-119.

Received 30 September 1996; revised 2 December 1996; accepted 12 December 1996. 